\title{
Comparative Histomorphological Studies on Oesophagus of Catfish and Grass Carp
}

\author{
Enas A. Abd El Hafez, Doaa M. Mokhtar, \\ Alaa Sayed Abou-Elhamd, and Ahmed Hassan S. Hassan \\ Department of Anatomy and Histology, Faculty of Veterinary Medicine, Assiut University, Assiut 71526, Egypt \\ Correspondence should be addressed to Alaa Sayed Abou-Elhamd; alaa88@yahoo.com
}

Received 8 May 2013; Accepted 30 July 2013

Academic Editor: Luigi F. Rodella

Copyright (C) 2013 Enas A. Abd El Hafez et al. This is an open access article distributed under the Creative Commons Attribution License, which permits unrestricted use, distribution, and reproduction in any medium, provided the original work is properly cited.

\begin{abstract}
The present work was carried out on 40 specimens of oesophaguses of both sexes of catfish (carnivorous fish) and grass carp (herbivorous fish) in order to observe the morphological and histological differences between the two species. Oesophagus of catfish was divided into 2 parts: anterior and posterior ones. The anterior part of the oesophagus of catfish was characterized by the presence of numerous mucosal folds. It was lined by stratified epithelium with goblet cells. In addition to club cells were observed in between the stratified epithelium. Scanning electron examination of the oesophageal epithelium of catfish demonstrated the presence of microvilli and fingerprint-like microridges in the superficial cell layer. The posterior part of the oesophagus of catfish was characterized by simple columnar mucus-secreting epithelium. The oesophagus of grass carp had shown the same structure along its entire length. It consisted of less folded mucosa than that observed in the oesophagus of catfish. The epithelium was characterized by the presence of taste buds. In conclusion, the present work revealed some differences in the structure of catfish oesophagus and grass carp oesophagus. These differences are related to type of food and feeding habits of each species.
\end{abstract}

\section{Introduction}

Nile catfish (Clarias gariepinus) is one of the most abundant and widely distributed fish in the Nile River. Catfish has a wide geographical spread, a high growth rate, resistant to handling and stress, and well appreciated in a wide number of African countries. It is considered the third important commercial fish in Egypt after tilapia and bagrids $[1,2]$. It can be recognized by its long dorsal and anal fins, which gives it a rather eel-like appearance. The catfish is carnivorous in type, where tilapias are its most preferred food item especially the young ones followed by insects, crustaceans, and mollusks, respectively [3]. The grass carp or white amur (Ctenopharyngodon idella) is a large cyprinid fish. They are native in large Asian rivers such as Amur River Basin in Russia and the West River in China [4]. It is a fast growing herbivorous fish; it usually feeds on grass or other aquatic vegetations and can be grown together with other fish species. The gastrointestinal tract of grass carp consisted of oesophagus, stomach, and intestine that ends at the anus. Food enters a short, often greatly distensible esophagus leading into a thick-walled stomach $[5,6]$. The histological structure of the gastrointestinal tract of numerous fish species generally consists of mucosa, submucosa, muscularis, and serosa. Results in previous studies have indicated that some differences of histological structures among fish gastrointestinal tracts are related to feeding habits, food, age, body shape, and weight $[7,8]$.

The aim of the present study is to describe and compare the anatomical and histological structures of the oesophagus of the catfish as an example of carnivorous fish and the grass carp as an example of herbivorous fish, using light and electron microscopy. This may provide a comparative basis for future studies of the feeding patterns of both species as well as a contribution to the development of fish farming.

\section{Materials and Methods}

The materials employed in this study consisted of randomly obtained 20 adult specimens of both sexes of the catfish 
Clarias gariepinus (represented as carnivorous fish) and 20 of grass carp Ctenopharyngodon idella (represented as herbivorous fish). The catfish specimens were collected from the Nile River at Elkhazan Bridge in Assiut city, and the grass carp samples were collected from a fish farm in El-Minea during the year. The specimens range from $35.40 \pm 3.01 \mathrm{~cm}$ for catfish to $37.20 \pm 4.0 \mathrm{~cm}$ for grass carp in standard length and from $406.40 \pm 9.60 \mathrm{gm}$ for catfish to $421.60 \pm 8.70 \mathrm{gm}$ for grass carp in body weight. After recording the previously mentioned biological measurements, fish of both species were dissected as soon as possible to obtain the oesophagus.

The oesophagus was dissected immediately and then put on a filter paper, and the length $(\mathrm{cm})$ and diameter $(\mathrm{cm})$ were measured using a caliber.

For histological studies, the samples were dissected as soon as possible from the anterior and posterior parts of the oesophagus of both species at $1 \times 1 \times 0.05 \mathrm{~cm}$ and were immediately fixed in Bouin's fluid for 24 hours. The fixed materials were dehydrated in an ascending series of ethanol, cleared in methyl benzoate, and then embedded in paraffin wax. Transverse and longitudinal paraffin sections at $5-8 \mu \mathrm{m}$ in thickness were cut and stained with Harris haematoxylin and eosin [9], Crossmon's Trichrome [10, 11], Periodic Acid-Schiff (PAS) technique [12], combined Alcian blue PAS technique [13], and Weigert's Elastica [14, 15].

Semithin Sections. Small pieces 2-3 mm long from the different portions of oesophagus of both species were placed in $2.5 \%$ cold glutaraldehyde in phosphate buffer ( $\mathrm{PH} 7.2)$ for 24 hours. The pieces were washed twice in $0.1 \mathrm{M}$ phosphate buffer and then postfixed in $1 \%$ osmium tetroxide, in the same buffer. The postfixed pieces were dehydrated in graded alcohols and embedded in araldite resin. Thin sections $(1 \mu \mathrm{m})$ in thickness were stained with $1 \%$ toluidine blue.

For scanning electron microscopy, formaldehyde-fixed specimens of oesophagus of both species were washed in $0.1 \mathrm{M}$ cacodylate buffer for $1 \mathrm{~h}$ and then transferred to a $1 \%$ solution of tannic acid for $2 \mathrm{~h}$ at room temperature. The pieces then were washed again in buffer and postfixed for $2 \mathrm{~h}$ in $1 \%$ osmium tetroxide. The postfixed materials were washed and dehydrated in a series of increasingly concentrated solutions. They were then mounted on aluminum stubs and sputtercoated with gold/palladium for $3 \mathrm{~min}$. The specimens were examined with a JEOL. JSM-5400 LV scanning electron microscope.

For transmission electron microscopy, small pieces 2$3 \mathrm{~mm}$ long from the different portions of anterior part of oesophagus of catfish were fixed and dehydrated as in semithin. Ultrathin sections obtained by a Reichert ultramicrotome were stained with uranyl acetate and lead citrate (Reynolds, 1963) and examined with a JEOL. JEM-100 electron microscope.

Morphometrical measurements were performed by using Image analysis system (Leica Q500MC). Measurements include diameter of the oesophagus, thickness of the wall, mucosa, submucosa and tunica muscularis, diameter of the lumen, number of mucosal folds/cross section, height and width of the mucosal folds, and height of the surface epithelium.

\section{Results}

3.1. Morphological Structure. The catfish had a slender blackish-coloured body without scales and a flat bony head, which took an eel-like appearance. The mouth was large terminal in position with four pairs of barbels (Figure 1(a)). The grass carp had an elongate, moderately compressed yellowish-green body with large scales. The head was broad and the mouth was small and subterminal in position without barbels (Figure 1(b)). The body weight, standard length, and total length of grass carp showed no significant increase compared with those of catfish (Table 1).

The oesophagus of catfish run from the posterior end of the pharynx anteriorly to the anterior part of cardiac region of the stomach caudally; being ventrally overlapped by the liver, its anterior region was wide and funnel-shaped and its posterior region was tubular in shape (Figure 1(c)). Its mean length was $0.78 \pm 0.20 \mathrm{~cm}$ (Table 1). The oesophagus of catfish was divided into two parts according to diameter and shape, the mean diameter of anterior part was $0.65 \pm 0.11 \mathrm{~cm}$ and posterior part was $0.48 \pm 0.09 \mathrm{~cm}$ (Table 1 ).

The oesophagus of grass carp run from the posterior end of the pharynx anteriorly to the intestinal bulb caudally, being ventrally overlapped by the liver and its shape was cylindrical and straight along its entire length (Figure 1(d)). The length of the oesophagus of grass carp showed no significant increase compared with that of catfish, its mean length was $1.16 \pm$ $0.23 \mathrm{~cm}$. It was not divided, as its diameter was the same along its entire length, its mean diameter was $0.51 \pm 0.10 \mathrm{~cm}$ (Table 1).

3.2. Histological Structure. The oesophagus of catfish was divided into 2 parts; anterior and posterior parts based on type and thickness of the epithelium and tunica muscularis.

3.2.1. Anterior Part of the Oesophagus of Catfish. The mean diameter of the anterior part of oesophagus was $5186.67 \pm$ $42.87 \mu \mathrm{m}$ and the mean thickness of its wall was $2461.15 \pm$ $48.11 \mu \mathrm{m}$ (Table 2). The wall of the oesophagus was formed of 4 distinct layers: tunica mucosa, tunica submucosa, tunica muscularis, and tunica adventitia.

The mean thickness of the tunica mucosa was $1397.33 \pm$ $59.49 \mu \mathrm{m}$ (Table 2). The mucosa consisted of approximately 36 parallel complex and elongated leaf-like folds that were referred to as primary, secondary, and tertiary folds. These folds were arranged longitudinally that occluded the lumen, which had a very complex folded appearance in histological cross sections (Figure 2(a)). Some wider channels of lumen were present; their mean diameter was $264.37 \pm 18.43 \mu \mathrm{m}$ (Table 2). The mean height of mucosal folds was $1190.80 \pm$ $32.58 \mu \mathrm{m}$ and their mean width was $172.48 \pm 5.88 \mu \mathrm{m}$ (Table 2). The mean height of epithelium was $112.49 \pm$ $2.74 \mu \mathrm{m}$ (Table 2). The epithelium was stratified cuboidal in type; the deeper layer was columnar, the middle layer contained a large number of goblet and club cells, while the superficial cells were cuboidal. This stratified epithelium had ill distinct cell boundaries, homogeneous acidophilic cytoplasm with rounded darkly stained nuclei. Occasional 


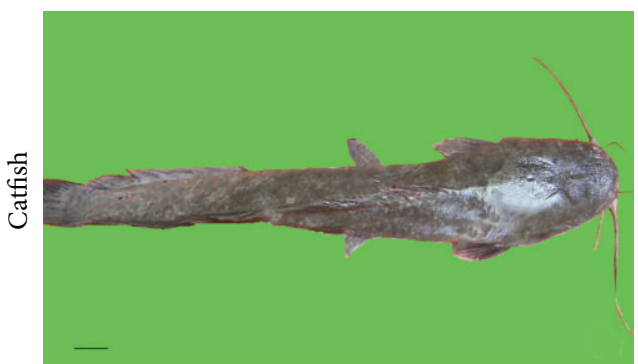

(a)

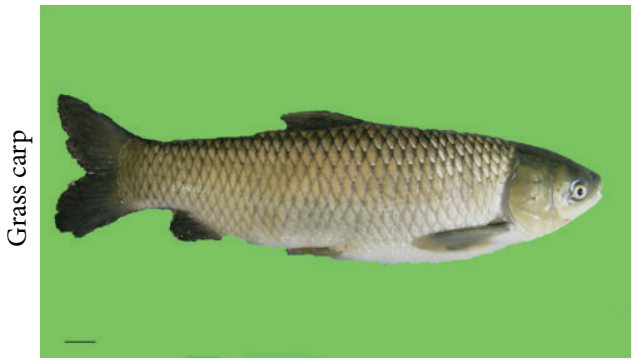

(c)

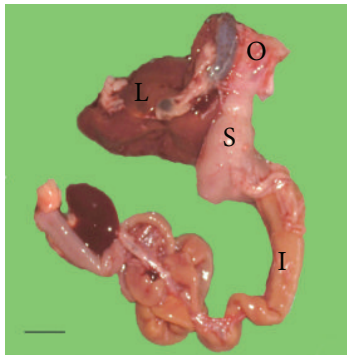

(b)

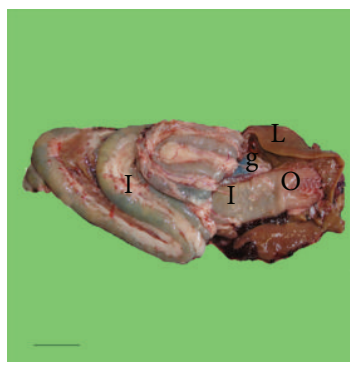

(d)

FIGURE 1: Photomicrographs of catfish and grass carp and their anatomical features of their oesophagi. (a) Dorsolateral view of catfish. (b) Photograph of the gastrointestinal tract of catfish, showing their oesophagus $(\mathrm{O})$, stomach $(\mathrm{S})$, which is overlapped by liver (L) and connected to intestine (I) caudally. (c) Lateral view of grass carp. (d) Photograph of the gastrointestinal tract of grass carp showing their oesophagus (O) connected to the intestinal bulb (IB). g: gall bladder. Bars: (a) $0.75 \mathrm{~cm}$; (b) $1.5 \mathrm{~cm}$; (c) $0.67 \mathrm{~cm}$; (d) $0.80 \mathrm{~cm}$.

leucocytes were found between the epithelial layers, especially in the basal part (Figure 2(b)). The epithelium also contained high density of club (alarm) cells. The club cells were large polyhedral cells with homogeneous acidophilic cytoplasm with 1-2 central rounded nuclei. These cells were located at different levels of the epithelial strata, but especially in the basal region of the epithelium (Figure 2(b)). They were PAS and Alcian blue negative (Figures 2(c) and 2(d)). By transmission electron microscopy, club cells appeared as large, polyhedral electron lucent, and binucleated cells. Their nuclei were polymorphic and euchromatic and contained electron dense nucleoli. Their cytoplasm contained many large elongated mitochondria and rough endoplasmic reticulum, which were arranged mainly around the nucleus. In addition, free ribosomes and many vesicles of different sizes were scattered all over the cytoplasm, which contained moderate electron dense secretory materials (Figure 3). Numerous rounded to oval goblet cells of different sizes were present in the superficial half of the epithelium. These cells appeared large with foamy cytoplasm and consisted of rounded mucous globules that were intensively stained with Alcian blue and PAS (Figures 2(c) and 2(d)). Lamina propria was composed of dense connective tissue, formed mainly of compactly arranged collagenous fibers, which extended to fill the core of the mucosal folds (Figure 2(e)).

Semithin sections showed that the mucosal epithelial cells were stratified in type and their superficial cells bore microridges, in addition to presence of toluidine blue-positive goblet cells. The goblet cells appeared spherical or oval in form and lacked the basal narrow part that was found usually at the base of these cells. The club cells appeared as giant polyhedral
TABLE 1: Showed statistical analysis of various measurements of catfish and grass carp.

\begin{tabular}{lcc}
\hline Measurements & Catfish & Grass carp \\
\hline Body weight $(\mathrm{gm})$ & $406.4 \pm 9.60$ & $421.60 \pm 8.70$ N.S. \\
Total length of fish $(\mathrm{cm})$ & $38.6 \pm 5.60$ & $40.60 \pm 6.21$ N.S. \\
Standard length of fish $(\mathrm{cm})$ & $35.4 \pm 3.01$ & $37.20 \pm 4.0$ N.S. \\
Length of oesophagus $(\mathrm{cm})$ & $0.78 \pm 0.20$ & $1.16 \pm 0.23$ N.S. \\
& $0.65 \pm 0.11$ & \\
Diameter of oesophagus $(\mathrm{cm})$ & (anterior part) & $0.51 \pm 0.10$ \\
& $0.48 \pm 0.09$ & \\
& (posterior part) \\
\hline
\end{tabular}

The values were represented by mean \pm standard error. Differences were considered as not significant if $P>0.05$ (N.S.), significant if $P<0.05$, and highly significant if $P<0.01$.

cells with pale staining cytoplasm. They were mononucleated or binucleated cells, where the two nuclei were situated very close to each other. Undifferentiated or basal cells were located at the base of the epithelium (Figure 4(a)).

Scanning electron microscopic observations of the mucosa of the anterior part of the oesophagus showed numerous primary, secondary, and tertiary longitudinal folds (Figure 5(a)). The outer layer of the epithelium was polyhedral in shape and exhibited prominent microvilli and fingerprint-like microridges (Figures 5(b) and 5(c)).

The mean thickness of the tunica submucosa was $460.72 \pm$ $16.72 \mu \mathrm{m}$ (Table 2). It was formed mainly of collagenous fibers. Bundles of striated longitudinal muscles were also observed in this layer (Figure 2(e)). The tunica muscularis 
TABLE 2: Measurements of oesophagus of both fish species and their relation (\%) to the wall measurements.

\begin{tabular}{|c|c|c|c|}
\hline \multirow{2}{*}{$\begin{array}{l}\text { Grass carp } \\
\text { Oesophagus }\end{array}$} & \multicolumn{2}{|c|}{ Catfish } & \multirow{2}{*}{ Measurements } \\
\hline & $\begin{array}{c}\text { Posterior part of } \\
\text { oesophagus }\end{array}$ & $\begin{array}{c}\text { Anterior part of } \\
\text { oesophagus }\end{array}$ & \\
\hline $4693.39 \pm 40.32$ & $4342.81 \pm 34.45$ & $5186.67 \pm 42.87$ & Diameter of the organ $(\mu \mathrm{m})$ \\
\hline $1998.27 \pm 43.37$ & $1504.61 \pm 12.77$ & $2641.15 \pm 48.11$ & Thickness of the wall $(\mu \mathrm{m})$ \\
\hline $\begin{array}{l}696.85 \pm 56.19 \\
14.84 \%\end{array}$ & $\begin{array}{c}1333.59 \pm 82.76 \\
30.70 \%\end{array}$ & $\begin{array}{c}264.37 \pm 18.43 \\
5.09 \%\end{array}$ & Diameter of the lumen $(\mu \mathrm{m})$ \\
\hline $\begin{array}{l}916.0 \pm 14.70 \\
45.83 \%\end{array}$ & $\begin{array}{c}299.68 \pm 10.23 \\
19.91 \%\end{array}$ & $\begin{array}{c}1397.33 \pm 59.49 \\
52.90 \%\end{array}$ & Thickness of the mucosa $(\mu \mathrm{m})$ \\
\hline $20.0 \pm 3.90$ & $26.41 \pm 7.10$ & $36.20 \pm 5.0$ & Number of mucosal folds/cross section \\
\hline $\begin{array}{l}655.56 \pm 14.38 \\
32.80 \%\end{array}$ & $\begin{array}{c}263.36 \pm 7.03 \\
17.50 \%\end{array}$ & $\begin{array}{c}1190.80 \pm 32.58 \\
48.38 \%\end{array}$ & Height of mucosal folds $(\mu \mathrm{m})$ \\
\hline $163.40 \pm 9.46$ & $104.55 \pm 1.8$ & $172.48 \pm 5.88$ & Width of mucosal folds $(\mu \mathrm{m})$ \\
\hline $\begin{array}{l}65.33 \pm 2.18 \\
3.26 \%\end{array}$ & $\begin{array}{c}28.60 \pm 1.37 \\
1.90 \%\end{array}$ & $\begin{array}{c}112.49 \pm 2.74 \\
4.57 \%\end{array}$ & Height of the epithelium $(\mu \mathrm{m})$ \\
\hline $\begin{array}{l}310.7 \pm 16.08 \\
15.54 \%\end{array}$ & $\begin{array}{c}216.69 \pm 7.50 \\
14.40 \%\end{array}$ & $\begin{array}{c}460.72 \pm 16.25 \\
17.44 \%\end{array}$ & Thickness of submucosa $(\mu \mathrm{m})$ \\
\hline $\begin{array}{l}861.07 \pm 72.78 \\
43.09 \%\end{array}$ & $\begin{array}{c}1070.54 \pm 6.32 \\
71.15 \%\end{array}$ & $\begin{array}{c}800.10 \pm 32.77 \\
30.28 \%\end{array}$ & Thickness of muscularis $(\mu \mathrm{m})$ \\
\hline
\end{tabular}

The values were represented by mean \pm standard error.

was composed of thick outer circular layer and thin inner longitudinal layer of striated muscles (Figure 2(e)). Its mean thickness was $800.10 \pm 32.77 \mu \mathrm{m}$ (Table 2). The anterior part of the oesophagus of cat fish is covered externally by tunica adventitia. It is formed of loose connective tissue which contained small blood vessels and elastic fibers (Figure 2(e)).

3.2.2. Posterior Part of Oesophagus of Catfish. The mean diameter of the posterior part of oesophagus of catfish was $4342.81 \pm 34.45 \mu \mathrm{m}$ and the mean thickness of its wall was $1504.61 \pm 12.77 \mu \mathrm{m}$ (Table 2).

As in the anterior part of the oesophagus, the wall of the posterior part was formed of 4 distinct layers: tunica mucosa, tunica submucosa, tunica muscularis, and tunica adventitia.

Tunica mucosa was a thin layer; its mean thickness was $299.68 \pm 10.23 \mu \mathrm{m}$, (Table 2 ). The mucosa contained approximately 26 short narrow and blunt folds. The oesophageal lumen became wider and less irregular than that of the anterior part (Figure 2(f)), its mean diameter was $1333.59 \pm$ $82.76 \mu \mathrm{m}$. The mean height of mucosal folds was $263.36 \pm$ $7.03 \mu \mathrm{m}$. The mucosal folds were narrower than the anterior part (Figure 2(f)), its mean width was $104.55 \pm 1.80 \mu \mathrm{m}$. The mean thickness of epithelium was $28.60 \pm 1.37 \mu \mathrm{m}$ (Table 2). The mucosal epithelium consisted of mucus secreting simple columnar epithelium (Figure 2(g)). The apical part of the epithelium reacted positively to PAS (Figure 2(h)). Lamina propria consisted of dense connective tissue, formed mainly of compactly arranged collagenous fibers, which extended to fill the core of the mucosal folds (Figure 2(i)).

Semithin sections showed that the mucosal epithelium of the posterior part consisted of tall columnar cells with middle oval light nucleus that contained distinct nucleoli. The apical part of these cells contained mucous granules, which reacted positively to toluidine blue. Some basal dark cells of irregular shape were present in the basal part of the epithelium (Figure 4(b)).

Scanning electron microscopic observations of the mucosa of the posterior part of oesophagus showed simple longitudinal folds (Figure 5(d)). The surfaces of polygonal epithelial cells exhibited short microvilli and small microridges. Numerous small holes for mucous extrusion in addition to some mucous droplets were present (Figures 5(e) and 5(f)).

Muscularis mucosa consisted of bundles of smooth muscle fibers, surrounded by numerous collagenous fibers (Figure 2(i)).

The mean thickness of the tunica submucosa was $216.69 \pm$ $7.50 \mu \mathrm{m}$ (Table 2). It was formed of dense connective tissue and contained numerous collagenous fibers. The striated muscles that were present in anterior part of the oesophagus diminished posteriorly and they were absent in the posterior portion of the oesophagus. This tunic was free of glands (Figure 2(i)).

The posterior part of the oesophagus had thicker muscularis than the anterior part, and it was composed of inner circular and outer longitudinal smooth muscle fibers that were held by connective tissue fibers (Figure 2(i)). Its mean thickness was $1070.54 \pm 6.32 \mu \mathrm{m}$, (Table 2).

The tunica adventitia was formed of loose connective tissue that contained collagenous fibers and small blood vessels (Figure 2(i)).

3.2.3. Oesophagus of Grass Carp. The oesophagus of grass carp was of the same structure and appearance along their entire length. Its mean diameter was $4693.39 \pm 40.32 \mu \mathrm{m}$ and the mean thickness of its wall was $1998.27 \pm 43.37 \mu \mathrm{m}$ (Table 2). 


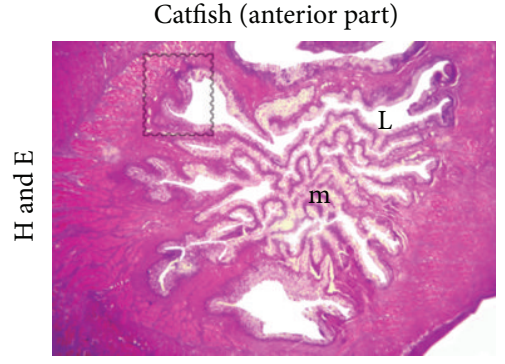

(a)

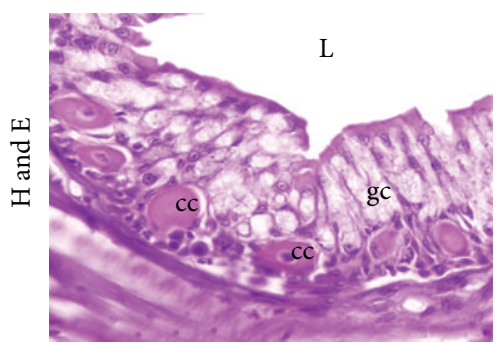

(b)

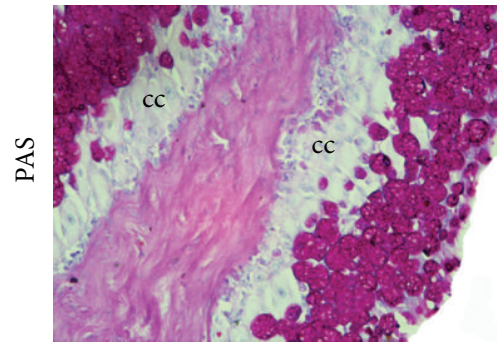

(c)

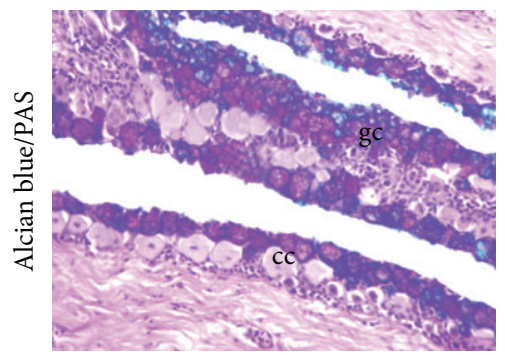

(d)

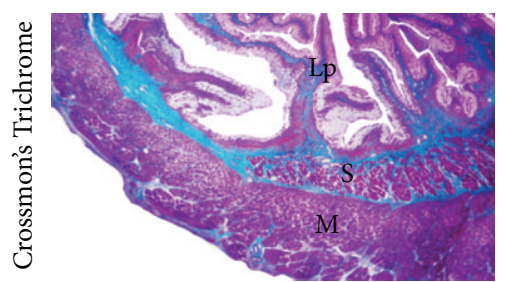

(e)

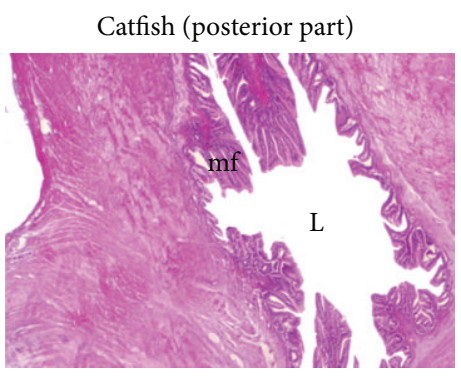

(f)

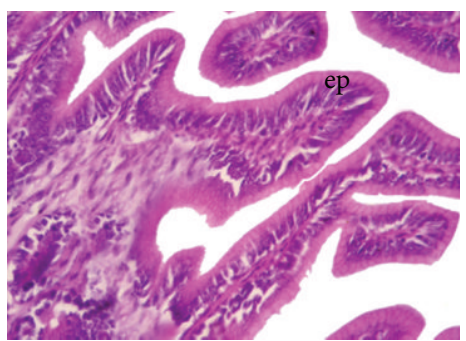

(g)

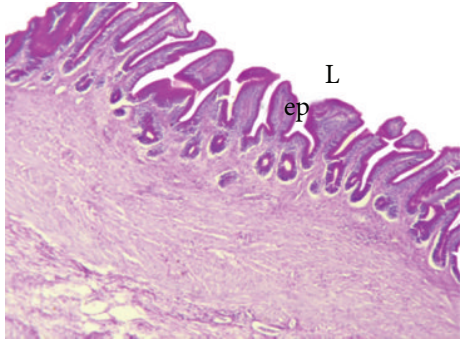

(h)

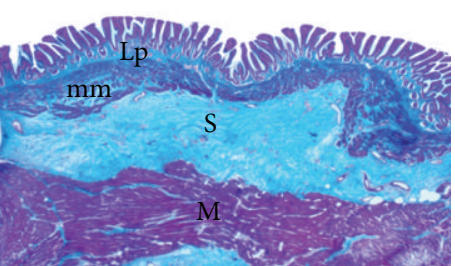

(i)

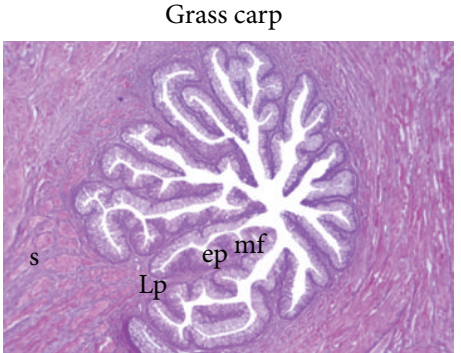

(j)

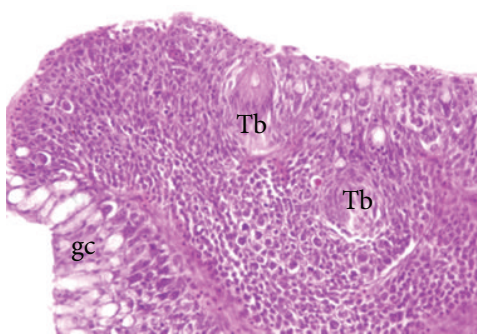

(k)

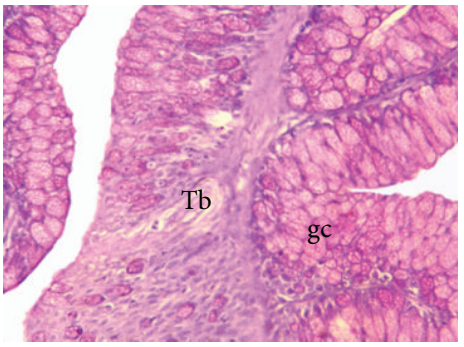

(l)

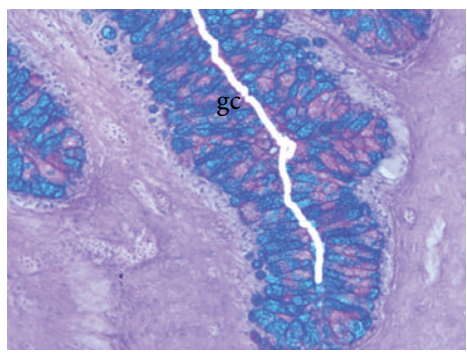

(m)

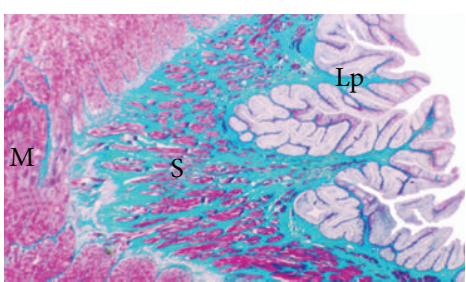

(n)

Figure 2: Photomicrograph showed the morphological characteristic features of the anterior part of oesophagus of catfish (a-e), posterior part of oesophagus of catFish ( $\mathrm{f}-\mathrm{i})$, and oesophagus of grass carp $(\mathrm{j}-\mathrm{n})$. Highly folded mucosa $(\mathrm{m})$; short mucosal folds (mf); wide channels of lumen (L); columnar epithelium (ep); goblet cells (gc); taste buds (Tb); club cells (cc). Notice the negative PAS reaction of club cells (cc), muscularis mucosa $(\mathrm{mm})$, lamina propria (Lp), tunica submucosa $(\mathrm{S})$, tunica muscularis $(\mathrm{M})$, and adventitia (ad). The square indicated one mucosal fold. (a), (e), (i), (f), (j), and (n) $\times 25$; (b), (c), (g), (k), and (l) $\times 400 ;(\mathrm{h}) \times 100$; (d) and (m) $\times 200$. 


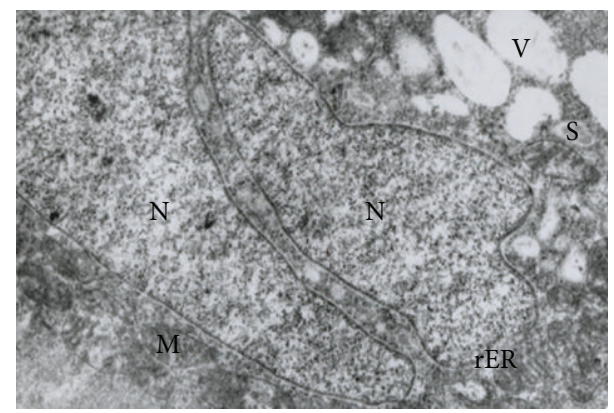

FIGURE 3: Transmission electron micrograph of the club cells of the anterior part of oesophagus of catfish showing 2 nuclei $(\mathrm{N})$, many vesicles $(\mathrm{V})$, moderate dense secretory materials (s), and mitochondria $(\mathrm{M})(\times 10000)$.

The mean thickness of the tunica mucosa was $916.0 \pm$ $14.70 \mu \mathrm{m}$ (Table 2), which constituted approximately $45.83 \%$ of the thickness of the wall. The mucosa was formed of a distinct longitudinal fold (about 20). The lumen was starshaped and appeared wider than in the anterior oesophageal part of catfish. The folds were generally narrow at the tip but were occasionally broadened in the basal part. The mucosal folds of the oesophagus of grass carp were shorter and less tortuous than in catfish (Figure 2(j)). Its mean diameter was $696.85 \pm 56.19 \mu \mathrm{m}$. The mean height of the folds was $655.56 \pm 14.38 \mu \mathrm{m}$ and its mean width was $163.40 \pm 9.46 \mu \mathrm{m}$. The mean height of the epithelium was $65.33 \pm 2.18 \mu \mathrm{m}$ (Table 2). The lining epithelium of the oesophagus of grass carp was of a stratified cuboidal type along its entire length, containing goblet cells and taste buds (Figure 2(k)). Oval and prominent taste buds were observed only in the most cranial portion of the oesophagus. It occurred between the epithelial cells in the form of fusiform bundles of pale spindle cells with oval nucleus, which were regard as gustatory cells. The exposed extremity of the taste bud was sunk in a pit, which was probably similar to the gustatory pore seen in mammals (Figure 2(k)). High properties of rounded goblet cells were found in patches, which was the most prominent and distinctive feature of the oesophageal epithelium of grass carp. Goblet cells were more numerous in the epithelium of the oesophagus of grass carp than those of catfish and reacted positively to PAS as fewer cells and Alcian blue as more numerous cells (Figures $2(\mathrm{l})$ and $2(\mathrm{~m})$ ). Lamina propria formed of finger-like processes of loose connective tissue, contained mostly collagenous fibers, numerous flattened fibroblasts, and thick longitudinal smooth muscle fibers. Thick layer of muscularis mucosa formed of isolated bundles of smooth muscle fibers located under the lamina propria (Figure 2(n)).

Semithin sections showed microridges in the apical part of the superficial epithelial cells of the oesophagus of grass carp. Undifferentiated basal cells were located at the base of the epithelium. Goblet cells were not found typically at the surface but usually were lain deeply and characterized by a metachromatic reaction to toluidine blue. Taste buds appeared as fusiform structure of pale cells with prominent taste pore (Figure $4(\mathrm{c})$ ).
Scanning electron microscope observation of the oesophageal mucosa revealed numerous folds that left distinct long concavities in between them (Figure $5(\mathrm{~g})$ ). Mucosa exhibited compactly arranged pentagonal or hexagonal surfaces of the superficial cells of the stratified epithelial cells (Figure 5(h)). The luminal plasma membrane of these cells presented complex or linearly arranged microridges in the form of an alveolar pattern. Discrete oval or circular openings of mucous cells were located between the stratified epithelial cells, which were slightly sunken with respect to the surrounding microridges. The network of alveolar microridges revealed that each cell was clearly limited by boundary microridges, so that the cellular contacts were marked by 2 parallel microridges (Figure 5(i)).

The tunica submucosa was formed of dense irregular connective tissue that contained collagenous fibers and numerous striated longitudinal muscle bundles that were sparsely distributed (Figure 2(n)). Its mean thickness was $310.70 \pm 16.08 \mu \mathrm{m}$ (Table 2$)$.

The mean thickness of the tunica muscularis was $861.07 \pm$ $72.78 \mu \mathrm{m}$ (Table 2). It was formed of inner circular and outer longitudinal layers of skeletal muscle fibers (Figure 2(n)). The oesophagus of grass carp was covered externally by tunica adventitia; which was formed of loose connective tissue, containing elastic fibers and blood vessels.

\section{Discussion}

The present work was carried out on 40 specimens of both sexes of catfish (carnivorous fish) and grass carp (herbivorous fish) in order to observe the morphological and histological differences between the two species. The results of the present work revealed some differences in the structure of the oesophagus of both species related to type of food and feeding habits of both species. The gastrointestinal tracts of fish show remarkable differences in function and structure, these differences were related to type of food, feeding habits, body weight, shape, and sex [16-18].

The present study revealed that the oesophagus of catfish was divided into anterior and posterior parts. The differentiation of oesophagus into two morphologically distinct zones, based on type and thickness of the epithelium and tunica muscularis has been documented in many fishes such as garfish [19]. While the oesophagus of grass carp had shown the same structure along its entire length.

The current observations revealed that the anterior part of the oesophagus of catfish was characterized by the presence of numerous mucosal folds that may allow maximal distension for prey and broken down food, and it was lined by stratified epithelium with goblet cells. The epithelium of the anterior part of the oesophagus of carnivorous fish acted as a constitutive adaptation that protected the oesophagus against live prey damages $[20,21]$. Moreover, the epithelium of the posterior part of the oesophagus was composed of simple columnar mucus secreting (PAS-positive) epithelium that may play a role in pregastric digestion. Also, the posterior oesophageal region acts as a site of selective ionic diffusion, so osmoregulatory functions are proposed for this epithelium, 


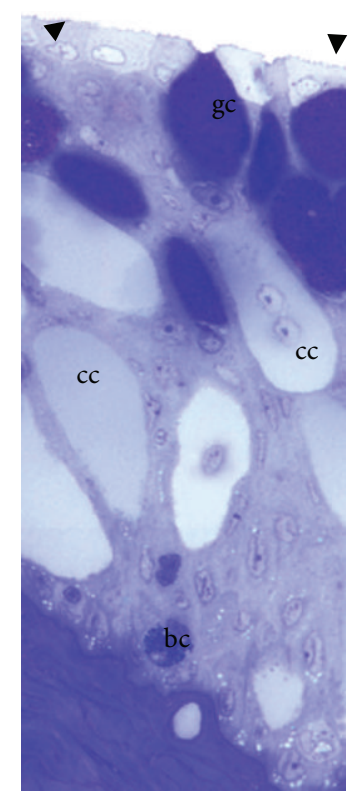

(a)

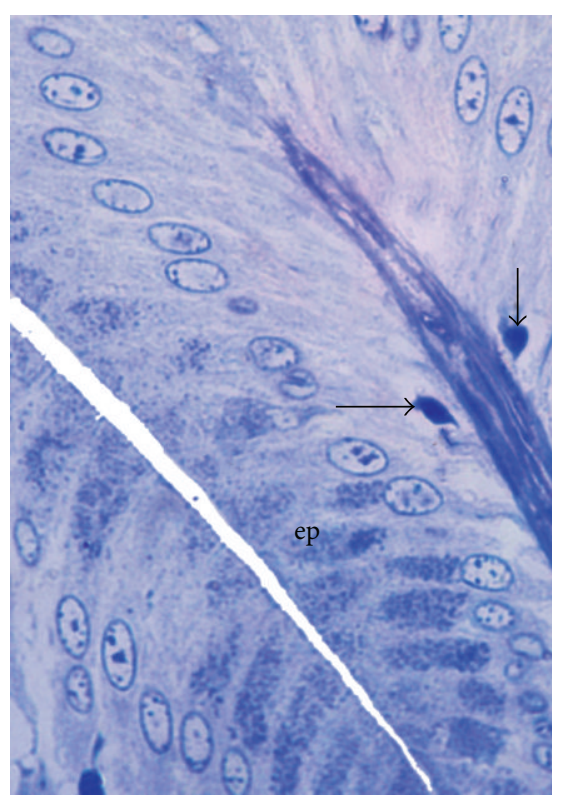

(b)

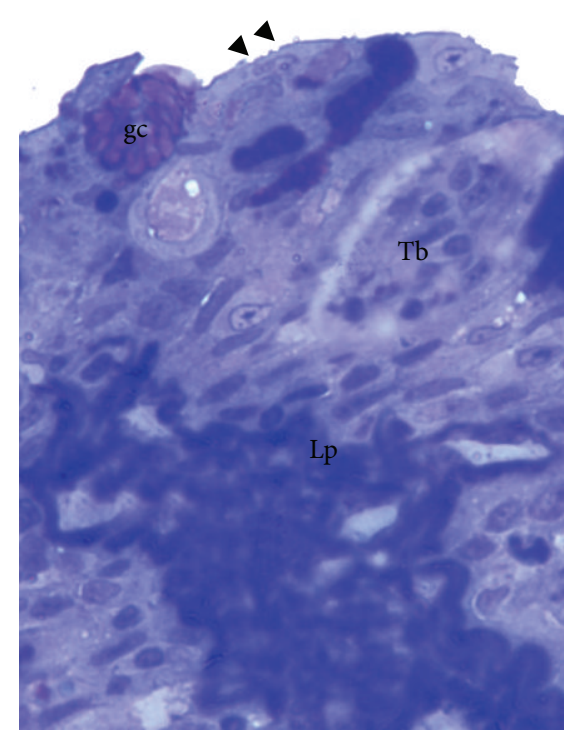

(c)

FIGURE 4: Semithin section of the stratified mucosal epithelium of the anterior part of oesophagus of catfish (a) showing the apical microridges (arrowheads), club cells (cc), goblet cells (gc), and basal cells (bc). In the posterior part of oesophagus of catfish (b), positive toluidine blue reaction was observed in apical epithelial cells (ep). Basal cells (arrow). (c) Oesophagus of grass carp showing microridges (arrowheads), metachromatic reaction of goblet cells (gc), and taste bud (Tb). Connective tissue lamina propria (Lp). (Toluidine blue, $\times 1000)$.

which are associated with wide blood vessels. In addition, it had an absorptive role [22-26].

Our results revealed that the oesophagus of both species possessed a high density of goblet cells as compared with other sections of the gastrointestinal tract. The increased number of goblet cells in the oesophagus of all fish species in general was probably due to the absence of salivary glands, as the mucin excreted in the oesophagus and buccal cavity compensates the absence of salivary glands in fish [27-31]. In addition, the oesophageal mucin has a role in enzymatic digestion of food via its contents of neutral mucosubstances, and it might have osmotic function through binding and transportation of water and ions content [30,31]. The goblet cells secrete both acid and neutral mucopolysaccharides, which play a role in the lubrication of food and protection of mucosa during swallowing. The mucus secreting cells shown in the present study are arranged in a continuous sheath in the oesophagus of grass carp, and this may provide rapid lubrication to the rough age-rich materials in the gut and to capture the excess of water from food particles during swallowing.

The present study revealed the presence of club cells in the anterior part of the oesophagus of catfish, which appeared as large acidophilic cells in between the lining stratified epithelium. The transmission electron microscopic observations revealed that the cytoplasm of the club cells contained rER, free ribosomes, mitochondria, and many vesicles, which contained electron dense secretory material. Several names have been given to club cells such as "clavate," "giant," and "alarm substance cells" [32,33]. The latter authors demonstrated the presence of the club cells in the skin and lips of many fish species that might be responsible for the induction of the fright reaction to other fish. These cells exude a proteinaceous secretion. When these secretions mixed in water are sensed by introducers through olfaction. So the main function of these cells is to induce the defensive behavior in fish. The defensive behavior of these cells was indicated in the production of toxic or antipathogenic agents, substances that deter predators; in addition, the club cells were shown to have phagocytic action by the ingestion of wandering cells. However, the previously mentioned authors added that the club cells must be damaged or broken before the alarm substances are released. Also, the structure of these cells in skin and lip differed from that in the oesophagus; in lip and skin, they had cytoplasmic processes and their cytoplasm contained fine coiled filaments. On the other hand, these cells were absent in the oesophagus of other fish species [34].

The basal part of the epithelium of the oesophagus of catfish contained undifferentiated cells. These cells undergo cytoplasmic changes and eventually become epithelial cells or goblet cells and also the club cells arise from it [35].

The present study demonstrated the presence of taste buds in the oesophagus of grass carp, indicating that the fishes select the type of food intake by either food rejecting or swallowing. The taste buds acted as chemoreceptors for specific selection of food before swallowing [20,36]. However, taste buds are present in the oesophagus of some species as sea bream, eel, and Oreochromis niloticus [21]. It is worth to mention that the epithelial lining of the oesophagus of grass carp performs various functions such as gustatory and mucus-producing to facilitate rapid and efficient swallowing action. 
Catfish (anterior part)

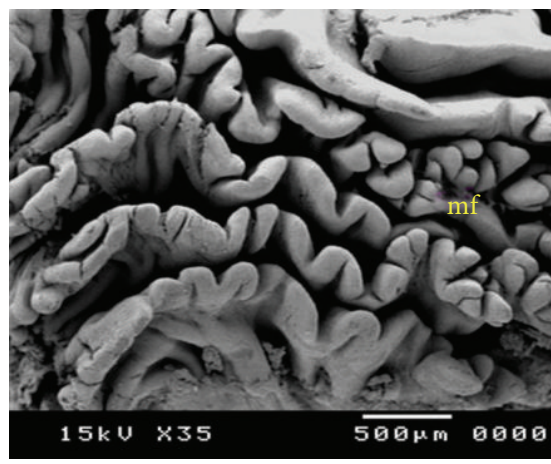

(a)

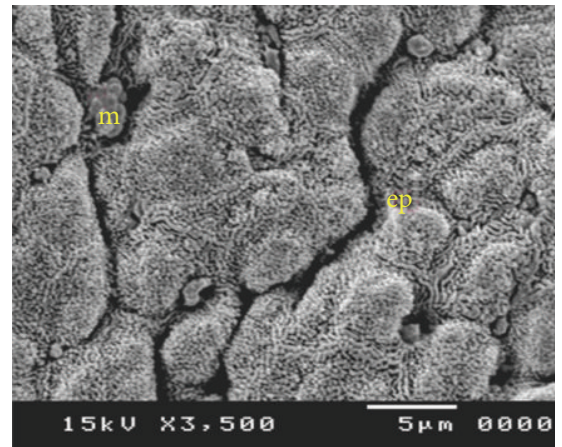

(b)

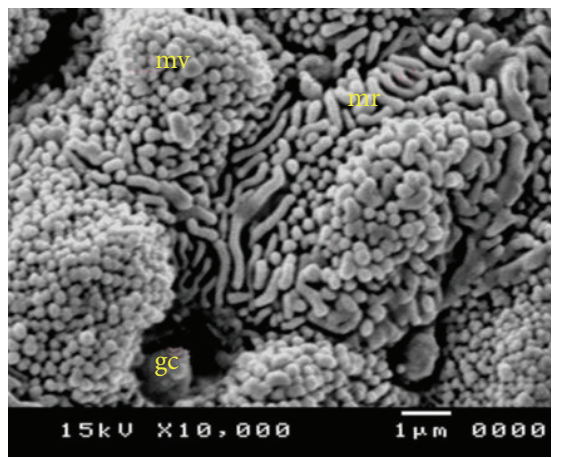

(c)
Catfish (posterior part)

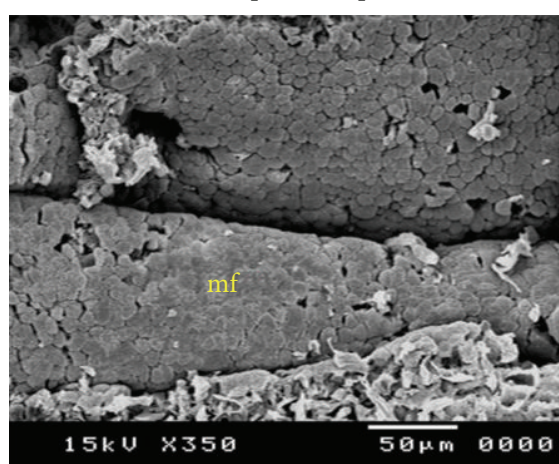

(d)

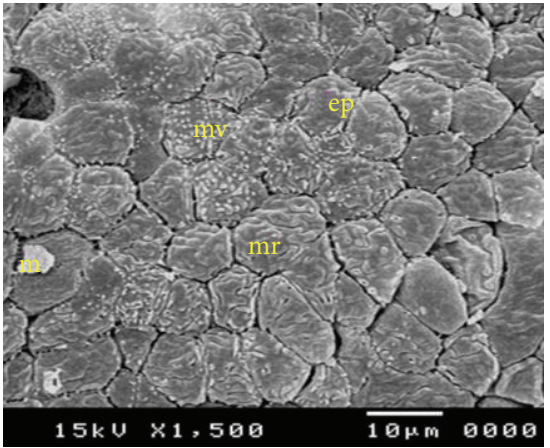

(e)

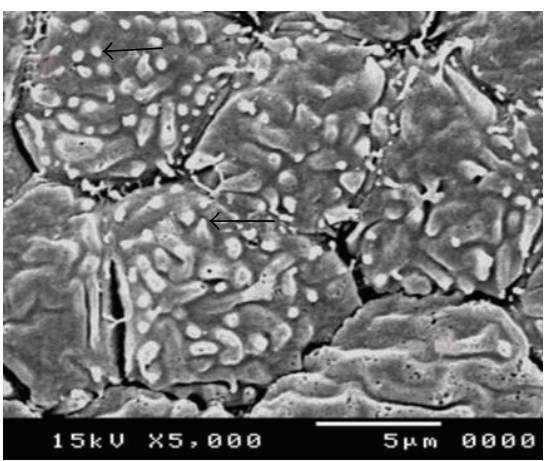

(f)
Grass carp

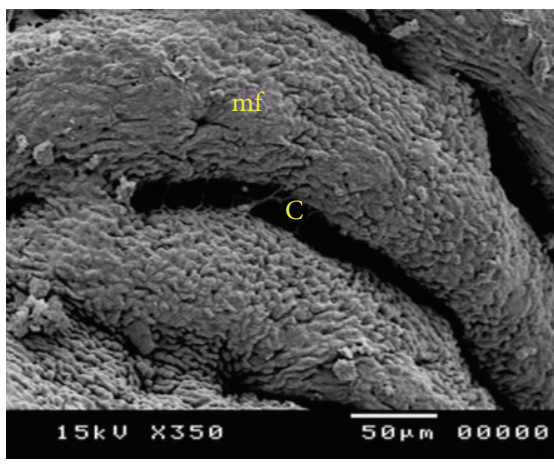

(g)

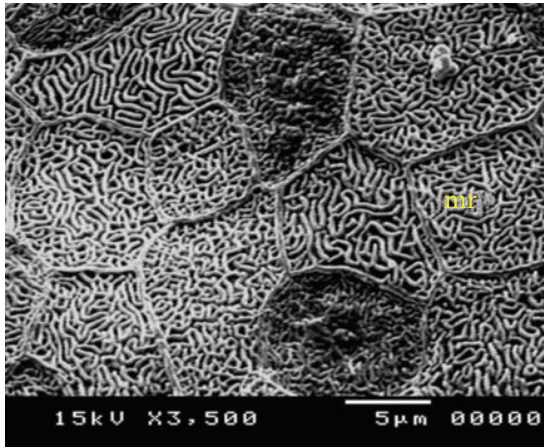

(h)

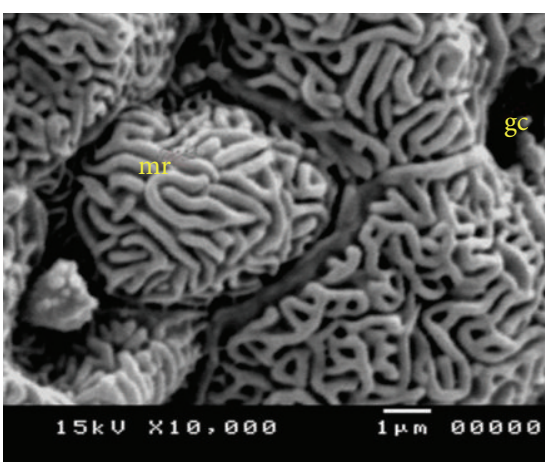

(i)

FIGURE 5: Scanning electron micrograph of the anterior part $(\mathrm{a}-\mathrm{c})$ and posterior part $(\mathrm{d}-\mathrm{f})$ of oesophagus of catfish and oesophagus of grass carp (g-i). Polyhedral-shaped superficial epithelial cells (ep). Mucosal folds (mf), microvilli (mv), microridges (mr), and long concavities (c) between them. Notice the presence of goblet cells (gc), microvilli (arrow), microridges (arrow head), and mucus (m).

Scanning electron microscopic examination of the oesophageal epithelium of catfish demonstrated the presence of microvilli in the superficial cell layer. The presence of these prominent microvilli indicates an adaptation to rapid ion absorption [22]. The fingerprint-like microridges observed in the superficial layer of the epithelium of the oesophagus of catfish may represent a mechanical adaptation that would withstand the trauma resulting from ingesting bulky materials. Furthermore, the alveolar pattern of microridges observed in the oesophageal epithelium of grass carp could perform other functions such as retaining and spreading mucus that creates an optimally lubricated surface for the passage of food, in addition to increasing the surface area of the epithelium lining the oesophagus and allowing the surface to stretch. Similar observations were recorded by [37]. Microridges were also observed in the epithelium of skin, gills, buccal cavity, and pharynx of some fish species [38].

Histological examination of the oesophagus of grass carp and catfish also revealed that the presence of numerous elastic fibers in the lamina propria and submucosa (data not shown) increases elasticity for swallowing large items of foods. In addition, the extensive core of lamina propria in the mucosal folds of oesophagus of catfish was probably to maintain the integrity of the wall and prevent rupture of the mucosal lining as it is to be stretched around the prey during the act of swallowing $[39,40]$.

Our results also revealed the presence of bundles of striated longitudinal muscles in the oesophageal submucosa. 
Otherwise, these striated muscles might be important for catfish to reject any unpalatable food and provide reinforcement to the oesophagus, which is subjected to violent extensions by ingestion of food. However, these muscles in submucosa of grass carp might be related to the coordination of the contraction of the oesophagus with movements of the pharyngeal teeth to allow expansion of the oesophagus for the ingestion of foods.

The thickness of the tunica muscularis particularly in the posterior part of the oesophagus of catfish might represent a powerful tool to strengthen the oesophageal wall, protect it from engorged bulky food, facilitate regurgitation, and also act as a triturating device for solid ingested materials [41]. Bucke found that the increased thickness of tunica muscularis of posterior part of the oesophagus of catfish that extended to gastric muscularis might play a role in increasing the motility, which optimize stomach digestion in carnivorous fish with irregular intakes of large quantities of food.

\section{References}

[1] A. Ayoade, S. Fagade, and A. Adebisi, "Diet and dietary habits of the fish Schilbe mystus (Siluriformes: Schilbeidae) in two artificial lakes in Southwestern Nigeria," Revista de Biologia Tropical, vol. 56, no. 4, pp. 1847-1855, 2008.

[2] M. M. Babiker, "Aspects of the biology of the catfish Clarias lazera (Cuv. \& Val.) related to its economic cultivation," Hydrobiologia, vol. 110, no. 1, pp. 295-304, 1984.

[3] S. Amisah, M. A. Oteng, and J. K. Ofori, "Growth performance of the African catfish, Claris gariepinus, fed varying inclusion levels of Leucaena leucocephala leaf meal," Journal of Applied Sciences and Environmental Management, vol. 13, no. 1, pp. 2126, 2009.

[4] V. Guillary and R. D. Gasaway, "Zoogeography of the grass carp in the United States," Transactions of the American Fisheries Society, vol. 107, no. 1, pp. 105-112, 1978.

[5] R. F. Sis, P. J. Ives, D. M. Jones, D. H. Lewis, and W. E. Haensly, "The microscopic anatomy of the oesophagus, stomach and intestine of the channel catfish, Ictalurus punctatus," Journal of Fish Biology, vol. 14, no. 2, pp. 179-186, 1979.

[6] M. Suiçmez and E. Ulus, "A study of the anatomy, histology and ultrastructure of the digestive tract of Orthrias angorae Steindachner, 1897," Folia Biologica, vol. 53, no. 1-2, pp. 95-100, 2005.

[7] H. A. Abdulhadi, "Some comparative histological studies on alimentary tract of tilapia fish (Tilapia spilurus) and sea bream (Mylio cuvieri)," Journal of Egyptian Journal of Aquatic Research, vol. 31, no. 1, pp. 387-397, 2005.

[8] R. Fugi, A. A. Agostinho, and N. S. Hahn, "Trophic morphology of five benthic-feeding fish species of a tropical floodplain," Revista Brasleira de Biologia, vol. 61, no. 1, pp. 27-33, 2001.

[9] H. F. Harris, "On the rapid conversion of haematoxylin into haematin in staining reactions," Journal of Applied Microscopy and Laboratory Methods, vol. 3, p. 777, 1996, Cited by J. D. Bancroft and A. Steven, Theory and Practice of Histological Techniques . 4th edition, New York, NY, USA, Churchill Livingstone, 1900.

[10] G. Crossmon, "A modification of Mallory's connective tissue stain with discussion of the principle involved," The Anatomical Record, vol. 69, pp. 33-38, 1989.
[11] P. Bock, "A modification of Mallory's connective tissue stain with discussion of the principle involved," in Romies Mikroscopishe Technik, Ubran and Schwarzenberg, Wiein, Germany, 17th edition, 1937.

[12] J. F. A. McManus, "Histological demonstration of mucin after periodic acid," Nature, vol. 158, no. 4006, p. 202, 1946.

[13] R. W. Mowry, "Alcian blue technics for the histochemical study of acidic carbohydrates," in Journal of Histochemistry and Cytochemistry, vol. 4, pp. 407-408, 1956.

[14] C. Wigert, "Ueber eine methode zur farbung elastischer fasern," Zentrablatt für Allgemeine Pathologie und Pathologische Anatomie, vol. 9, p. 289292, 1898.

[15] J. D. Bancroft and A. Steven, Theory and Practice of Histological Techniques, Churchill Livingstone, New York, NY, USA, 4th edition, 1996.

[16] J. T. Eastman and A. L. DeVries, "Morphology of the digestive system of Antarctic nototheniid fishes," Polar Biology, vol. 17, no. 1, pp. 1-13, 1997.

[17] K. Çinar and N. Şenol, "Histological and histochemical characterization of the mucosa of the digestive tract in flower fish (Pseudophoxinus antalyae)," Journal of Veterinary Medicine C, vol. 35, no. 3, pp. 147-151, 2006.

[18] M. Monsefi, Z. Gholami, and H. Esmaeili, "Histological and morphological studies of digestive tube and liver of the Persian tooth-carp, Aphanius persicus (Actinopterygii: Cyprinodontidae)," Journal of Biology, vol. 69, no. 1, pp. 57-64, 2010.

[19] M. Jaroszewska and K. Dabrowski, "Morphological analysis of the functional design of the connection between the alimentary tract and the gas bladder in air-breathing lepisosteid fish," Annals of Anatomy, vol. 190, no. 4, pp. 383-390, 2008.

[20] S. M. El-Gharbawy, T. F. Sallam, and H. El-Habback, "Posthatching age changes of the oesophagus of tilapia fish (Oreochromis niloticus) light and tem studies," Veterinary Medical Journal Giza, vol. 49, no. 3, pp. 451-472, 2001.

[21] C. M. Santos, S. Duarte, T. G. L. Souza, T. P. Ribeiro, A. Sales, and F. G. Araújo, "Histology and histochemical characterization of the digestive tract of Pimelodus maculatus (Pimelodidae, Siluriformes) in Funil reservoir, Rio de Janeiro, Brazil," Iheringia, vol. 97, no. 4, pp. 1-9, 2007.

[22] M. F. Meister, W. Humbert, R. Kirsch, and B. Vivien-Roels, "Structure and ultrastructure of the oesophagus in sea-water and fresh-water teleosts (Pisces)," Zoomorphology, vol. 102, no. 1, pp. 33-51, 1983.

[23] W. Humbert, R. Kirsch, and M. F. Meister, "Scanning electron microscopic study of the oesophageal mucous layer in the eel, Anguilla anguilla L," Journal of Fish Biology, vol. 25, pp. 117-122, 1984.

[24] Z. Kozarić, S. Kužir, Z. Petrinec, E. Gjurčević, and N. Baturina, "Histochemistry of complex glycoproteins in the digestive tract mucosa of Atlantic bluefin tuna (Thunnus thynnus L.)," Veterinarski Arhiv, vol. 77, no. 5, pp. 441-452, 2007.

[25] A. O. Díaz, A. M. García, and A. L. Goldemberg, "Glycoconjugates in the mucosa of the digestive tract of Cynoscion guatucupa: a histochemical study," Acta Histochemica, vol. 110, no. 1, pp. 76-85, 2008.

[26] M. A. Abaurrea-Equisoain and M. V. Ostos-Garrido, "Cell types in the esophageal epithelium of Anguilla anguilla (Pisces, Teleostei). Cytochemical and ultrastructural characteristics," Journal of Micron, vol. 27, no. 6, pp. 419-429, 1996.

[27] E. Cataldi, D. Crosetti, G. Conte, D. D'Ovidio, and S. Cataudella, "Morphological changes in the oesophageal epithelium during 
adaptation to salinities in Oreochromis mossambicus, O. niloticus and their hybrid," Journal of Fish Biology, vol. 32, no. 2, pp. 191-196, 1988.

[28] I. R. Tibbetts, "The distribution and function of mucous cells and their secretions in the alimentary tract of Arrhamphus sclerolepis krefftii," Journal of Fish Biology, vol. 50, no. 4, pp. 809-820, 1997.

[29] M. P. Albrecht, M. F. N. Ferreira, and E. P. Caramaschi, "Anatomical features and histology of the digestive tract of two related neotropical omnivorous fishes (Characiformes; Anostomidae)," Journal of Fish Biology, vol. 58, no. 2, pp. 419430, 2001.

[30] V. Pedini, P. Scocco, G. Radaelli, O. Fagioli, and P. Ceccarelli, "Carbohydrate histochemistry of the alimentary canal of the shi drum, Umbrina cirrosa L," Anatomia, Histologia, Embryologia, vol. 30, no. 6, pp. 345-349, 2001.

[31] L. Marchetti, M. Capacchietti, M. G. Sabbieti, D. Accili, G. Materazzi, and G. Menghi, "Histology and carbohydrate histochemistry of the alimentary canal in the rainbow trout Oncorhynchus mykiss," Journal of Fish Biology, vol. 68, no. 6, pp. 1808-1821, 2006.

[32] Y. Iger, M. Abraham, and S. E. Bonga, "Response of club cells in the skin of the carp Cyprinus carpio to exogenous stressors," Cell and Tissue Research, vol. 277, no. 3, pp. 485-491, 1994.

[33] A. A. Sandhu, Thesis, Type, Punjab, Pakistan, 2000.

[34] A. B. Abol-Munafi, P. T. Liem, M. V. Van, and M. A. Ambak, "Histological ontogeny of the digestive system of marine goby (Oxyeleotris mammoratus) larvae," Journal of Sustainability and Management, vol. 1, no. 2, pp. 79-86, 2006.

[35] K. N. Hirji, "Observations on the histology and histochemistry of the oesophagus of the perch, Perca fluviatilis L.," Journal of Fish Biology, vol. 22, no. 2, pp. 145-152, 1983.

[36] D. N. Ezeasor, "Light and electron microscopic studies on the oesophageal epithelium of the rainbow trout, Salmo gairdneri," Anatomischer Anzeiger, vol. 155, no. 1-5, pp. 71-83, 1984.

[37] D. K. Mandal and P. Chakrabarti, "Architectural pattern of the mucosal epithelium of the alimentary canal of Notopterus notopterus (Pallas) and Oreochromis mossambicus (Peters): a comparative study," Acta Ichthyologica et Piscatoria, vol. 26, no. 1, pp. 15-22, 1996.

[38] M. A. Ali, "Ultrastructural study on the lining epithelium of the oral roof of the catfish (Clarias gariepinus)," Kafr El-Sheikh Veterinary Medical Journal, vol. 4, no. 1, pp. 71-87, 2006.

[39] J. M. Grizzle and W. A. Rogers, Anatomy and Histology of the Channel Catfish, Auburn University Agricultural Experiment Station, Auburn, Ala, USA, 1976.

[40] J. M. Manjakasy, R. D. Day, A. Kemp, and I. R. Tibbetts, "Functional morphology of digestion in the stomachless, piscivorous needlefishes Tylosurus gavialoides and Strongylura leiura ferox (Teleostei: Beloniformes)," Journal of Morphology, vol. 270, no. 10, pp. 1155-1165, 2009.

[41] D. Bucke, "The anatomy and histology of the alimentary tract of the carnivorous fish the pike Esox lucius L," Journal of Fish Biology, vol. 3, no. 4, pp. 421-431, 1971. 

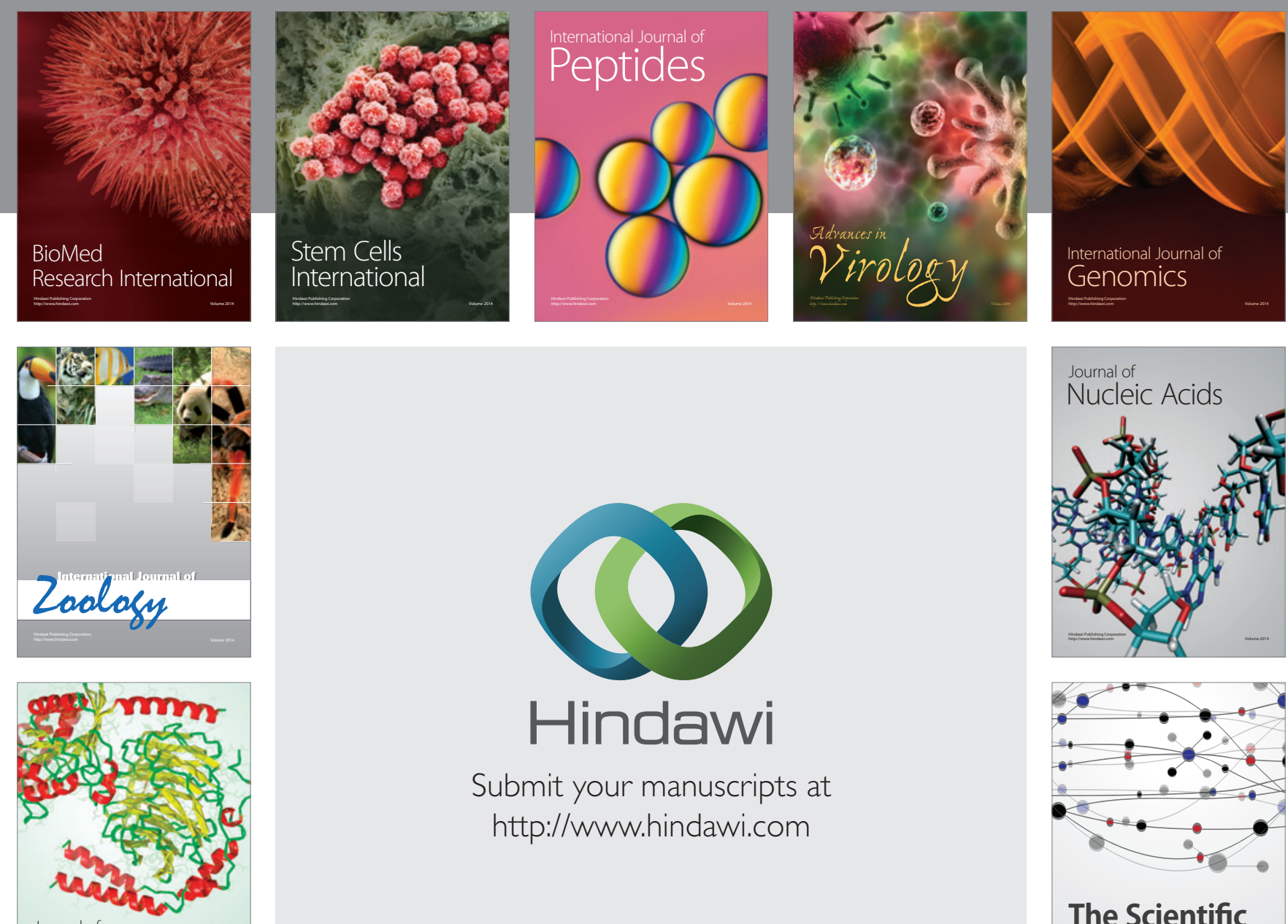

Submit your manuscripts at

http://www.hindawi.com

Journal of
Signal Transduction
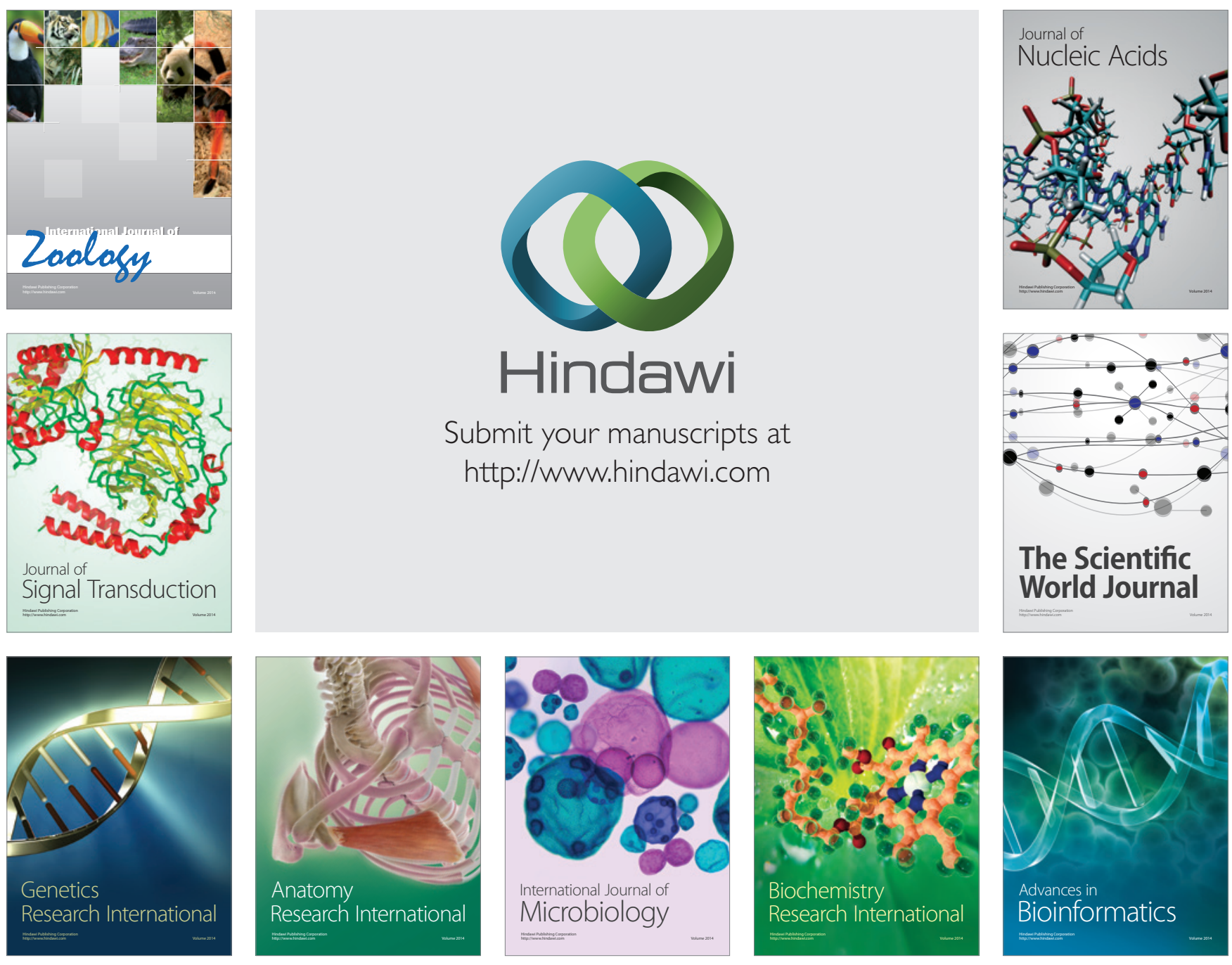

The Scientific World Journal
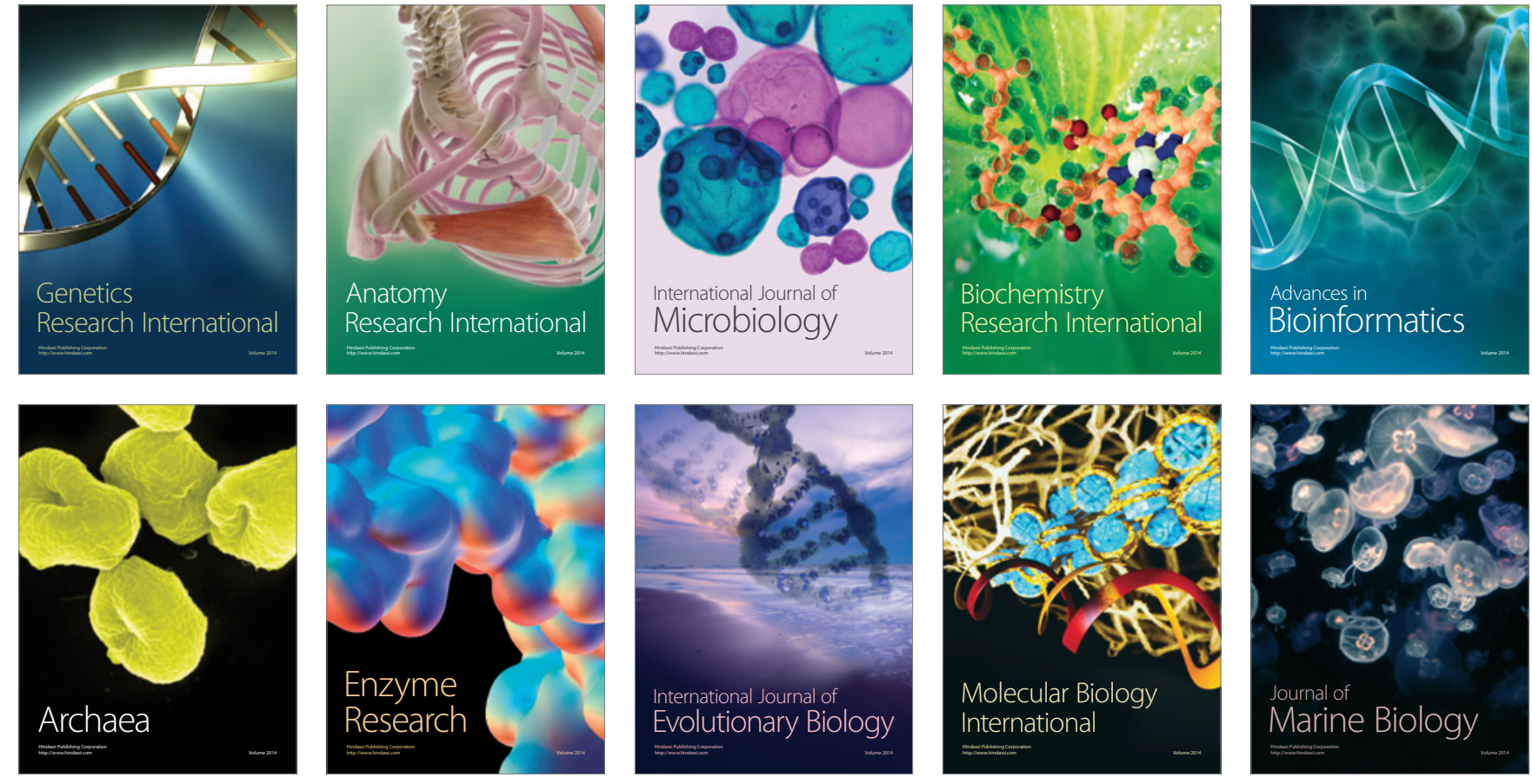